\title{
Analysis of Climate Smart Agricultural Practices Among Maize Farmers in Funtua Agricultural Development Zone of Katsina State, Nigeria
}

\author{
Akinyemi Mudashiru ${ }^{1}$, Adeola Segun Solomon ${ }^{1}$, Hassan Christiana Onyohu ${ }^{2}$, \\ Balogun Stanley Olusegun $^{3}$, Ekpa Daniel ${ }^{1}$, Adaraniwon Bolaji Samuel ${ }^{1}$, Hassan Muili Tunde ${ }^{4}$ \\ ${ }^{1}$ Department of Agricultural Economics, Federal University Dutsin-Ma Katsina State, Nigeria \\ ${ }^{2}$ Department of Economics, Accounting \& Finance, Bells University of Technology, Ota, Ogun State, Nigeria \\ ${ }^{3}$ Department of Agricultural Management, Forest Research Institutes, Afaka, Kaduna State, Nigeria \\ ${ }^{4}$ Department of Chemical Fibre and Environmental Technology, Federal Institutes of Industrial Research, Lagos, Nigeria
}

Email address:

makinyemi@fudutsinma.edu.ng (A. Mudashiru)

\section{To cite this article:}

Akinyemi Mudashiru, Adeola Segun Solomon, Hassan Christiana Onyohu, Balogun Stanley Olusegun, Ekpa Daniel, Adaraniwon Bolaji Samuel, Hassan Muili Tunde. Analysis of Climate Smart Agricultural Practices Among Maize Farmers in Funtua Agricultural Development Zone of Katsina State, Nigeria. International Journal of Agricultural Economics. Vol. 6, No. 2, 2021, pp. 71-77. doi: 10.11648/j.ijae.20210602.12

Received: August 1, 2020; Accepted: February 20, 2021; Published: March 17, 2021

\begin{abstract}
Farming techniques in sub-Saharan African is not progressing at the same stride with advancement of modern agriculture practice. The resultant effects are obscenest and foulest recital in agricultural productivity which culminate in food insecurity, impoverishment and deprived national economy. This study examined climate smart agricultural practices among maize farmers in Funtua agricultural development zone of Katsina State. Primary data was collected with the aid of structured and pre-tested questionnaire administered to One hundred and sixty respondents using multi-stage sampling technique. Questionnaire administration was done by the researchers abetted by trained enumerators. Data collected from respondents was analyzed using both descriptive and inferential statistics. Socio-economic diagnosis shows that the mean age of the respondents was 48 years. This suggests that majority of the maize CSAP practioners in the study area are in their youthful age and mainly (53\%) are fully involved in maize farming with majority $(75 \%)$ having more than 11 years maize farming experience. This implies that most of the maize farmers are energetic, this can translate to better performance in maize farming activities. The majority of the farmers (68\%) are educated. This would further enhanced in espousal of CSAP technology. The study further revealed that the most CSAP techniques in the study area is minimum tillage and mixed farming as used by $90 \%$ of the respondents, while about $85 \%$ of the maize farmers interviewed practiced cover cropping. Inferential statistics reveals that coefficient of multiple determination R-squared value of $51.5 \%$. Three out of seven exogenous variables were significant, these are Household size, farm size and education. Household size was negatively significant $(\mathrm{P}<0.01)$. It implies that an increase in the size of the farming household would decrease the practice of CSAP in the study area. Education was positively significant $(\mathrm{P}<0.01)$. This connotes that advancement in farmers education will influence the practice of CSAP in the study area. Farm size was positively $(\mathrm{P}<0.1)$. This implies that an increase in the farm size will stimulate the practice of CSAP among the maize farmers. The study concludes that there are ample evidences of CSAP activities among maize farmers in Funtua agricultural zone. The study recommends that bottleneck occasioned from non-availability of land for maize production should be tackled through government intervention. Knowledge update with respect to CSAP farming techniques should be championed by the farmers' group and agricultural institutions. Household size should be regulated and synchronized with focus on agricultural productivity.
\end{abstract}

Keywords: Climate-Smart, Agricultural-Practices, Maize-Farmers, Katsina-State, Nigeria 


\section{Introduction}

The primacy on Agriculture had been on high in the political agenda of Nigeria as it is increasingly recognized as one of the key drivers of economic change [11], Agriculture which comprises of four sub-activities (crop production, livestock, forestry and fishing) is the mainstay of Nigeria's economy, being that over $70 \%$ of the people rely on rain fed agriculture [12]. Agriculture contributes significantly to the country's GDP, accounting for about 25.13 percent of real GDP in Nigeria. [14]. Nigeria like some other West African countries, Maize (Zea mays), is one of the main crop produce virtually in all the agroecological zones in Nigeria. It is the highest yielding grain crop having multiple uses [9]. Maize has established itself as a very significant component of the farming system, it determines the cropping pattern of the predominantly peasant farmers in Northern Nigeria and has been of great importance in providing food for man, feed for livestock and raw materials for some agro-based industries. It constitutes a staple food for a large population in developing countries like Nigeria $[3,6]$

Unfortunately, like every other activity in the agricultural sector, Maize crop production and yield is threatened by changing climatic conditions. [2] Climate change affects agriculture in a number of ways including through changes in average temperature, rainfall and climate extremes. Though climate change is experienced worldwide, it impacts on agriculture are varied over space and time, the effects are heterogeneous across countries and highly uncertain. It is alleged that its effect on developing countries will be worst due to two key reasons: most of them are highly agricultural based and hence rely on climatic conditions for survival; second they lack the technological capacity to adequately forecast, mitigate and adapt to these changes collectively and nationally. [16] In Nigeria, climate change is forecasted to have a devastating negative impact on agriculture in Nigeria lowering crop productivity, especially maize over the entire country with a predicted loss of $30-50 \%$ by 2020 and as much as $90 \%$ by the year 2100 with greater impact affecting maize crop in northern Nigeria $[7,10]$. In addition, changing rainfall pattern will increase the incidence of pest, diseases, drought and flooding; this will eventually increase the possibility of food shortages and price increase, thus wiping out most of the gains made in reducing poverty that will be realized without climate change. [11, 5]. According to Abubakar and Yamusa 2013, Climate change has caused reduction in the production of staple food especially maize [1]. This ultimately affects food prices and make households to spend more on food consumption which ultimately culminate in nutritional shortage and insufficient access to food. [4]. Northern Nigeria has a comparative advantage in cereal production and government must make a concerted effort to harness its production potentials and lift maize industry to an enviable heights. The climate smart agricultural practices offer a worthwhile solution to solve the myriads of challenges occasioned from climate change threatening maize farmers.
It is on this backdrop that this study sought to investigate the economics of the use of climate smart agricultural practices (CSAP) among maize farmers in Funtua Agricultural development zone of Katsina state, Nigeria. Specifically, the study intends to identify the CSAP among maize farmers, estimate the determinants of the factors influencing the level of climate smart agriculture practices and identify the problems facing farmers in practising climate smart agriculture

\section{Conceptual and Theoretical Framework}

Climate-smart agriculture (CSA) can be defined as an approach for transforming and reorienting agricultural development under the new realities of climate change (3). The most commonly used definition is provided by the Food and Agricultural Organization of the United Nations [13], which defines CSA as "agriculture that sustainably increases productivity, enhances resilience (adaptation), reduces/removes Green House Gases (mitigation) where possible, and enhances achievement of national food security and development goals". In this definition, the principal goal of CSA is identified as food security and development (4); while productivity (sustainable increase agricultural productivity and incomes from crops, livestock and fish, without having a negative impact on the environment), adaptation (strengthening resilience by building capacity to adapt and prosper in the face of shocks and longer-term stresses.), and mitigation (reduce and/or remove greenhouse gas (GHG) emissions) are identified as the three interlinked pillars necessary for achieving this goal. The application of CSA cuts across the various agricultural activities including crop production. The examples of CSA interventions include soil management, drought-tolerant, dairy development, farming catfish intensively, carbon finance to restore crop fields, waste-reducing rice thresher, rainfall forecasts and incentive system for low-carbon agriculture.

Considering the low and dwindling maize turn over in the Nigeria, there is a need for a comprehensive approach that incorporates the abilities to increase agricultural productivity and incomes sustainably now and in the future; adapts and build resilience to climate change and reduces or removes greenhouse gases emission using local knowledge and initiatives. Moreover, despite the drastic forecasts of the possible effect of climate change on agriculture, there has been inadequate evident empirical assessment of the level of mitigation of climate change as a result of CSAP in northern Nigeria. At this point, it is clear to see why though research on the impact of climate change is important for all sectors in Nigeria, concern for agriculture is paramount. Though traditional farmers are known to engage in what could be defined as climate friendly practices, yet the extent these practices affected maize production and the factors influences farmers' choices of the type of CSAP that is being adopted to in the Northern Nigeria is unknown. 


\section{Materials and Method}

\subsection{Study Area}

The study was conducted in Funtua Local Government Area of Katsina State, Nigeria. Funtua LGA which was created in 1976 is agrarian area in the northern guinea savannah vegetation zone of Nigeria. It has a sub-humid environment closer to the semi-arid agro climatic region [8]. It has land mass area of $448 \mathrm{~km}^{2}$ and a population of 570,110 people according to 2016 estimate. It is located on coordinate of $11^{0} 32^{1} \mathrm{~N}$ and $7^{0} 19 \mathrm{E}$. The area borders with Giwa Local Government of Kaduna state to the east, Danja to the southeast, Faskari to the northwest, and Dandume to the west. The major occupation of the people includes; trading, crop farming, and animal rearing. Major crops grown in the area include cereals such as maize, sorghum and millet. The major ethnic groups in the area are hausa-fulani, Yoruba, Igbo, Ibira, Tiv, Igala, Gwari, and other Nigeria ethnic groups.

\subsection{Sampling Size and Procedure}

Primary data used for the study was collected with the aid of structured pre-tested questionnaire administered to the respondents by the researcher and trained enumerators. A multi stage sampling technique was used for the study. The first stage involved a purposive selection of four LGAs namely Bakori, Danja, Funtua and Kankara out of eleven LGAs namely Dandume, Danja, Bakori, Faskari, Sabuwa, Kankara, Malumfashi, Kafur, Musawa, Matazu and Funtua that made up funtua agricultural development area. These are major maize producing LGAs in the KARTADA zone. The second stage involves a random selection of twenty (20) villages by selecting five villages from each local government. These are: Jabiri, Mai-Ganiji, Mairuwa, Makera and Maska from Funtua LGAs. Lmajiraiwa, Arewa, Bagoma, Burdugu and Da-Kumeji, from Kankara LGAs. Jiba, Kahutu, Tandama, Yakaji and Majedo from Danja LGAs and finally Tsiga, Jargaba, Kabomo, Barde, Dawan-Musa from Bakori LGAs. The final stage involved the selection of eight (8) farmers from each village to give birth to a total of one hundred and sixty (160) maize farmers used for this study. Data were collected on the socio economic characteristics of respondents, types of climate smart agricultural practices available and used in the study area.

\subsection{Analytical Techniques}

Descriptive statistics such as frequency count, percentages and means were used for this study. Multiple regression was also used. The explicit form of the regression model is expressed thus

$$
\beta_{0}+\beta_{1} X_{1}+\beta_{2} X_{2}+\beta_{3} X_{3}+\beta_{4} X_{4}+\beta_{5} X_{5}+\beta_{6} X_{6}+\beta_{7} X_{7}+\varepsilon
$$

Where;

$\mathrm{Y}=$ count of CSAP (\#)

$\beta_{0}=$ constant

$\beta_{1}-\beta_{7}=$ coefficient of the variables.

$\mathrm{X}_{1}=$ Age (years),

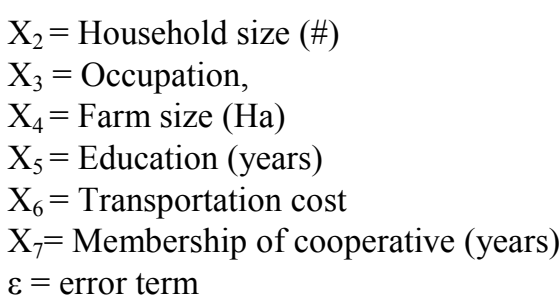

\section{Result and Discussion}

\subsection{Socio Economic Characteristics of the Maize Farmers}

Table 1 presents the results of the socio-economic characteristics of the maize farmers among whom the study was conducted. The Table 1 revealed that $25 \%$ of maize farmers were within the age range of 27-44 years. Majority $(50 \%)$ of the maize farmers are within the age group of $45-53$ years while the mean age of the respondents was 48 years. This suggests that most of the maize farmers in the study area are in their youthful age. This implies that most of the maize farmers are energetic and will be able to do well in maize farming activities. By virtue of their age also, adopting better practices will be easier.

The study also as presented on Table 1 shows that all of the respondents $(100 \%)$ are male. This is unsurprising being that maize farming activities in the area requires tedious works that requires energy. In terms of marital status, about $94 \%$ of the respondents are married. Since almost all the respondents' family men, by implication, there will be labour available for use on the farm though it will depend on the number of people in the family. Education is an important socio-economic characteristic that relates to usage of technology. The study, as presented on Table 1 reveals that majority $(61 \%)$ of the farmers in the study area had at least secondary school education. This shows that they are literate and should not find it too difficult to accept innovations.

Household distribution shows that most of the maize farmers (about 48\%) have household size of between 11 and 15 people. Depending on the age composition, labour availability will usually guarantee labour for farming. Furthermore $14 \%$ of the respondents have household size of 1-10 while about $13 \%$ have more than 20 persons within their households. The mean household size of the maize farmers in the study area was 14 persons. This is an advantage for punctual and steady supply of household labour for farm operations.

The occupation distribution from table 1 shows that majority of the farmers (53\%) engaged primarily in crop farming. This shows that maize farming is a main activity for the respondents. Furthermore, about $27 \%$ and $12 \%$ are engaged in livestock farming and petty trading as their major occupation respectively. This means therefore also that these categories of farmers do not depend primarily on maize farming as their source of income. Other occupations include those who are primarily engaged as automobile mechanic as their occupation. Sometimes, these farmers spend monies made from these primary sources in maize farming. 
The experience of the farmers shows that about half of them have between 11 and 15 years maize farming experience. Those who have 1-5 years and 6-19 years maize farming experience are $12.5 \%$ and $12.5 \%$ respectively. Those who have more than 20 years maize farming experience constitutes only $5 \%$.

Table 1 shows the result of size of maize farm cultivated by the respondents. Majority (55\%) of the maize farmers cultivated between 10-14 hectares of farmland and just a few (about 4\%) cultivated 1-4 ha of maize. Furthermore, about $40 \%$ of the maize farmers grow between 10 and 14 ha of maize per season. Looking more closely, about $95 \%$ of the respondents have at least 5 ha of maize and at most 14 ha. This shows that most of the maize farmers in the study area are medium and large scale farmers who grow maize for commercial purposes.

Table 1. Socio-economic Characteristics.

\begin{tabular}{|c|c|c|}
\hline & Frequency & Percentage (\%) \\
\hline \multicolumn{3}{|l|}{ Age } \\
\hline $27-35$ & 20 & 12.5 \\
\hline $36-44$ & 20 & 12.5 \\
\hline $45-53$ & 80 & 50 \\
\hline $54-62$ & 32 & 20 \\
\hline $63-71$ & 8 & 5 \\
\hline \multicolumn{3}{|l|}{ Marital Status } \\
\hline Single & 4 & 2.5 \\
\hline Married & 150 & 93.75 \\
\hline Widow/widower & 2 & 1.25 \\
\hline Divorced & 4 & 2.5 \\
\hline \multicolumn{3}{|l|}{ Level of Education } \\
\hline Qur'anic Education & 38 & 24 \\
\hline Primary Education & 14 & 9 \\
\hline Secondary Education & 98 & 61 \\
\hline Tertiary Education & 10 & 6 \\
\hline \multicolumn{3}{|l|}{ House hold size } \\
\hline $1-5$ & 02 & 1.3 \\
\hline $6-10$ & 20 & 12.6 \\
\hline $11-15$ & 76 & 47.6 \\
\hline $16-20$ & 42 & 26 \\
\hline $21-25$ & 06 & 3.9 \\
\hline $26-30$ & 10 & 6 \\
\hline $31-35$ & 04 & 2.6 \\
\hline \multicolumn{3}{|l|}{ Major occupation } \\
\hline Crop farming & 84 & 52.5 \\
\hline Livestock farming & 42 & 26.25 \\
\hline Petty trader & 18 & 11.25 \\
\hline Mechanic & 16 & 10 \\
\hline \multicolumn{3}{|l|}{ Years of experience } \\
\hline $1-5$ & 20 & 12.5 \\
\hline $6-10$ & 20 & 12.5 \\
\hline $11-15$ & 80 & 50 \\
\hline $16-20$ & 32 & 20 \\
\hline $21-25$ & 08 & 5 \\
\hline \multicolumn{3}{|l|}{ Farm size $(\mathrm{Ha})$} \\
\hline $1-4$ & 06 & 3.8 \\
\hline $5-9$ & 64 & 40.1 \\
\hline $10-14$ & 88 & 55.1 \\
\hline $15-19$ & 02 & 1 \\
\hline
\end{tabular}

Source: Field Survey 2019.

Climate Smart Agricultural Practice in the study Area

Table 2 shows the various practices of CSAP used in mitigating the effect of climate change in the study area, the most practiced climate smart practice here is minimum tillage and mixed farming as used by $90 \%$ of the respondents. Minimum tillage causes less disturbance of the soil; it does not turn the soil over. It is contrary to intensive tillage which changes the soil structure using ploughs. Reduced soil cultivation decreases farm energy requirements and overall farming cost as less area has to be tilled [15]. Furthermore, in the northern Nigeria, mixed farming is quite popular among cattle rearers. It is quite common to see these farmers' supplementing their livestock farming with crop cultivation thus the cost of farming is reduced due to the provision of feeds and fertilizers by the animals and crops respectively. Mulching is the next most used CSAP in the study area (by $89 \%$ of the respondents). This is probably due to the high temperature obtainable in the northern part of Nigeria because Mulching reduces surface water loss. Cover cropping on the other hand is often used to prevent soil from being depleted or eroded and to improve soil quality and organic matter content. About $85 \%$ of the maize farmers 
interviewed practiced the cover cropping. Mixed cropping and Crop rotation are CSAP used by $65 \%$ and $44 \%$ of the farmers in the area respectively. Crops are usually mixed to reduce risks of total loss as a result of crop failure. Crop rotation on the other hand is the practise of growing a series of dissimilar or different types of crops in the same area in sequenced season, it is done that the soil of farms is not used for only one set of nutrients, rather Crop production is increasingly vulnerable to risks associated with new and evolving climatic changes. Other CSAP used in the area are use of organic manure, water harvesting, agro-forestry and planting of drought resistant crop varieties as practiced by $7 \%, 7 \%, 9 \%$ and $9 \%$ of the maize farmers in the study area respectively. Irrigation management is one of the least used CSAP in the study area although about $29 \%$ of the respondents still practice that. Retaining and incorporating refuse to soil and Retaining and incorporating refuse to soil were used by $31.3 \%$ of the respondents respectively.

Table 2. Climate Smart Agricultural Practices in the Study Area.

\begin{tabular}{|c|c|c|c|}
\hline Climate smart agricultural Practices & Frequency & Percentage $(\%)$ & Rank \\
\hline Cover cropping & 68 & 85 & 4 \\
\hline Minimum tillage & 72 & 90 & 1 \\
\hline Mulching & 71 & 89 & 3 \\
\hline Mixed farming & 72 & 90 & 1 \\
\hline Mixed cropping & 52 & 65 & 5 \\
\hline Crop rotation & 35 & 44 & 6 \\
\hline A forestation & 28 & 35 & 11 \\
\hline Planting of drought tolerance crop varieties & 27 & 38 & 9 \\
\hline Use of organic manure & 32 & 40 & 7 \\
\hline Water harvesting & 28 & 40 & 7 \\
\hline Agro forestry & 27 & 38 & 9 \\
\hline Conservation agriculture & 26 & 33 & 12 \\
\hline Terracing & 25 & 31.3 & 14 \\
\hline Improved varieties & 24 & 30 & 16 \\
\hline Retaining and incorporating refuse to soil & 25 & 31.3 & 14 \\
\hline Use of wetland soil conservation techniques & 26 & 33 & 12 \\
\hline
\end{tabular}

Source: Field Survey 2019.

\subsection{Factors Influencing Climate Smart Agriculture Practice}

Table 3 below presents the estimated determinants of the level of CSAP selected by the maize farmers in the study area. The result shows that the regression model has a coefficient of determination of about $18 \%$. This implies that the independent variables are responsible for about $18 \%$ of the variations that occur in the dependent variables (Number of CSAP used by the farmers). The result shows that only household size and farm size were the variables that significantly affect the number of CSAP used by the maize farmers. The coefficient of household size is significant at $1 \%$ level of probability but having a negative relationship with the number of CSAP used by the maize farmers. The a priori expectation however is the reverse. On the other hand, the coefficient of farm size is significant at $10 \%$ level of probability with a positive relationship with the number of CSAP used by the maize farmers. This shows that the number of CSAP used by the farmers increases with increase in their farm sizes. This implies that as farm sizes increases the maize farmers becomes increasingly intolerant to risks and as such will be ready to scout for any possible ways of mitigating the negative effect of climate change. Other variables like the age of the farmers, their membership of cooperatives, cost of transportation from their homes to farm, their secondary occupation were found not to have significantly influenced the maize farmers to select more or less of the available CSAP in the study area.

Table 3. Determinants of the factors influencing the level of CSAP used.

\begin{tabular}{lllll}
\hline Variables & Coefficients & Standard Error & t-value & p-value \\
\hline Age & 0.0410 & 0.7427 & 0.0551 & 0.5831 \\
Household size & -0.3087 & 0.0919 & 3.3603 & $0.0014^{* * *}$ \\
Occupation & -0.8363 & 0.5628 & 1.4858 & 0.1421 \\
Farm size & 0.3832 & 0.1735 & 2.2091 & $0.0782^{*}$ \\
Education & 0.1586 & 0.0376 & 4.2140 & $0.0018^{* * *}$ \\
Cost of transportation & 0.0069 & 0.0071 & 0.9817 & 0.3309 \\
Membership Cooperative & -0.2885 & 1.2349 & 1.2282 & 0.2231 \\
Constant & 10.45032 & 5.932802 & 1.7614 & 0.082 \\
\hline
\end{tabular}

Source: Field Survey 2019.

$\mathrm{R}^{2}=51.5 \%$

sig at $10 \%{ }^{* * *}$ sig at $1 \%$. 


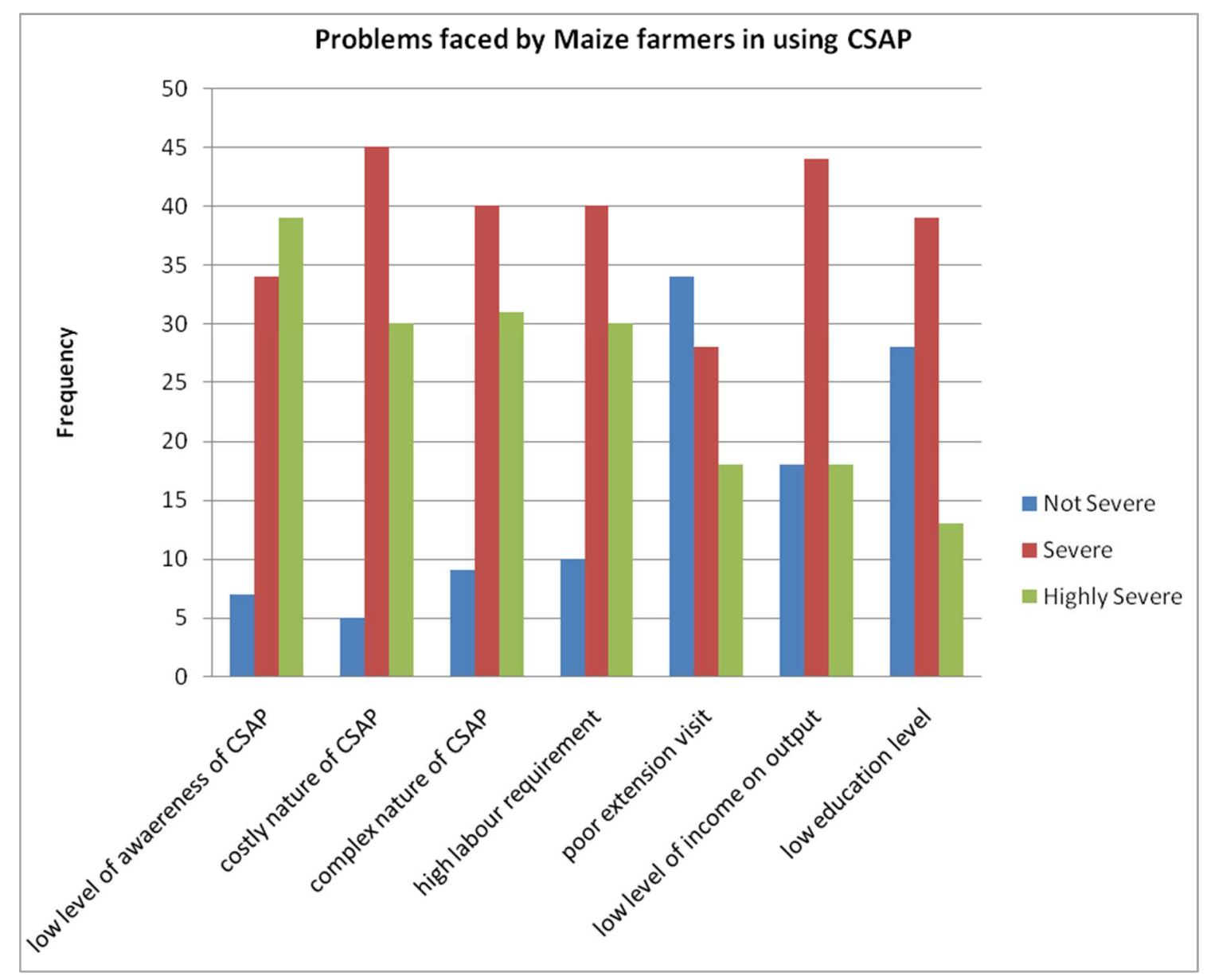

Figure 1. Histogram showing the problem faced by CSAP farmers.

\section{Major Problems faced by CSAP Practioners}

Figure 1 presents the major problems highlighted by the maize farmers in their usage of CSAP in maize production. Poor extension visit has the highest frequency in the not severe ratings implying that most of the farmers are not seen it as a major problem. This confirms that the farmers have adequate extension visits as indicated in the socio-economic sections. Costly nature of some CSAP ranked highest among the severe category while low level of awareness was rated the most highly severe problem. Some of the CSAP might not involve buying anything but are labour intensive. This might be the reason why the farmers complain about costs. Also complex nature of the CSAP and their high labour requirements were rated severe by forty (40) maize farmers in the study area while majority of the farmers rated low level of education as a severe problem in the usage of CSAP. This is worrisome because the study also revealed that a substantive number of the respondents had more that primary school education. However, this might only reveal the fact that there is low quality of education among the maize farmers.

\subsection{Conclusion and Recommendation}

The study concludes that there are ample evidences of CSAP activities among maize farmers in Funtua agricultural zone. The following recommendations can be made from the research work

To increase the hectarage maize cultivation bottleneck occasioned from non-availability of land for maize production should be tackled through government intervention.

The education of the farmer can be enhanced by updating Knowledge with respect to CSAP farming techniques which can be championed by the farmers' group and agricultural institutions.

Household size should be regulated and synchronized with focus on agricultural productivity.

\section{References}

[1] Abubakar, I. U., and Yamusa, M. A. (2013): Recurrence of Drought in Nigeria: Causes, Effects and Mitigation International Journal of Agriculture and Food Science Technology. 4 (3), 169-180.

[2] Adebayo Adewale Emmanuel and Ojogu Ekum (2019): Assessment of the Use of Climate Smart Agricultural Practices among Smallholder Farmers in Ogun State Acta Scientific Agriculture 3 (6), 23-31.

[3] Andohol, J. D. (2012): Nigeria's Food Security Programs: Implications for MDG's Goal of Extreme Hunger Eradication. International Journal of Business and Social Science 3 (9), 32-43. 
[4] Ekpa, D., Oladele, O. I. and Oyekale, A. S. (2017): Evaluation of Factors Influencing Indicators of Climate Smart Agricultural Practice on Crop in North-West Nigeria World Journal of Agricultural Research. 5 (5), 273-278.

[5] Ekpa, D., Akinyemi, $M$ and Ibrahim, H. I (2017): Investigating Climate Agricultural practices in Livestock production in Sokoto State, Nigeria: An Application of Principal Component Analysis FUDMA Journal of Sciences 1 (1), 10-18.

[6] Ekpa, D. and Oladele, O. I (2018) Poverty Status of Climate Smart Agricultural Farmers in North West Nigeria: Application of Foster Greer and Thorbecke Model. American Journal of Rural Development. 3 (5), 138-149.

[7] Fanen, T. and Adekola O., (2014)."Assessing the role of climate-smart agriculture in combating climate change, desertification and improving rural livelihood in Northern Nigeria" African Journal of Agricultural Research. 9 (15), $1180-1191$

[8] Godstime, J., Idris, K. and Haliru, Ahmad (2018): Assessment of Environmental Sensitivity to Desertification in Katsina State, Nigeria Environment and Ecology Research. 6 (6): 545555 .

[9] Helena, P., Just, D., Mona, D., Christene, P and Gerard, B (2018) Enhancing Food System in Nigeria: Scope and perspective for Policy intervention. Wageningen University and Research. Royal Tropical Institute.

[10] Iken, J. E. and Amusa, N. A. (2004): Maize research and production in Nigeria. African Journal of Biotechnology. 3 (6), 302-307.

[11] Intergovernmental Panel on Climate Change IPCC, (2001). "Climate Change: The Scientific Basis". Cambridge University Press. The Edinburgh Building, Cambridge CB2 2RU, United Kingdom. Khanal, U., Thapa, K. and Thapa, K. B., (2013). "Climate Change Adaptation Practices against Water Scarcity in High Mountain Areas". In: Udas, R., Thapa, K. and Lamsal, K. (eds.).

[12] Leslie, L., Philiph, K. T and Bruce, M. C (2014): ClimateSmart Agriculture for Food Security. Nature Climate Change. 4 (1) 1068-1072.

[13] Obayelu, E. A. and Obayelu, O. A. (2014): Strengths, Weaknesses, Opportunities And Threats (Swot) Analysis Of The Nigeria Agricultural Transformation Agenda (Ata) Nigerian Journal of Agricultural Economics (NJAE). 4 (1), 25-43.

[14] Maimuna, Y. and Benedict, A. (2015): Neglecting Agriculture and its Consequences to the Nigerian Economy: An Analytical Synthesis European Journal of Research in Social Sciences 3 (3), 24-37.

[15] Suleiman Ladan (2017): Analysis of the Constraints to Agricultural Development in Bakori Local Government Area, Katsina State. Ewemen Journal of Plant Genetic and Chemotaxonomy 2 (1), 15-25.

[16] Peter M. K., Neal W. M., Peng, W., Brigid, A. M and Enzo LI (2019): Soil and the intensification of agriculture for global food security. Environmental International 132 (1). 